\title{
雜娽
}

\section{生産 戰と碍子規格に就いて}

\section{加藤 祿 郎}

近代戰の特徵は何であるかといへば其れは國家總力戰である，過 去の戰爭の如く單に武力のみにては勝ち得ない. 武力と共に生產力 が相應に伴はねばなら奴。國民一人一人が戰爭目的に向つて總ての 力を發揮し其の力の總計の如何によつて勝負が決せらるっことであ ろ.

前線銃後の言葉，或は觀念は最早やなく何れを見て子戰線であつ て第一線か第二線かである。第一線は武力戰線であり，第二線は生 座戰線である.完勝不敗の態勢とは實にこの生産陣の强固さを言ふ ものであらう.

真に國家の存亡を睹する大戰を背負ふ我等生蒦戰線にあるるのは この不敗態勢を整へ米英壓服へと常に最高度の生缓に向つて努力し 第一線の消耗に對し不安なからしむべく，其の補給を强化し，强力 なる生產陣を布かねばならない。此の大東亞戰を消耗戰なりと稱へ らる 所以子實にこ」に存するのですつて, 其の重要性は一㕌深く 身邊に感ぜられ生產戰線にある者としての責任の如何に重大なるか を銘記せしめらるっのである. 又一面科學戰とも稳せられ，科學陣 營は第一線にして科學戰に於ける科學者は自己の生死はなく, 唯國 家のために敵擊隇へ精魂を集結し戰ふべきである。

生產戰或は科學戰陣營は其の日的逐行のため最も有效適切なる方 策の樹立が必要であつて, 其れには科學技術の下に資源, 動力, 勤 勞の 3 者が整然一體となつて, より高度なる生産を擧げ得べき樣式 を整へねばならない。

高度なる生產確保のための合理的なる 進行過程として考ふべき基 點としては, 何を措いても規格制定, 及其れの實行徹底化ではなか らうか. 此の基點こそは資源節約, 動力節約, 勤勞篩約として擧げ られ，之れは取も直さず不足資源, 不足動力, 不足勞力を充足へと 導くもので, 我が國策なる大東亞新秩序建設圈建設の雄渾なる構想 の中に織込するべき恒久的な中核的方策として取上げねばならない 所のもので, 缺くべからざる生產强化の, 或は攄充の法則と言ふす 過言ではなからう。何れの產業部門と雖もこの法則たる規格化の徹 底を必要とせざるはなく特に重要鏟業部門に於ては佮更である。

然し乍ら我が國產業の多くは規格に對して未げ全面的なる實行が なく，又規格制定を見ざる部門さへあり，此の不統一の部門が消隇 し全面的に規格中心に生座可能なる日が來てこそ正しく新秩序建設 圈建設機構の確立する日であり，決戰完勝態勢の整ふ日であらう.

故に規格は常に資源, 動力, 勤勞の 3 者の中心軸を成し, 決戰一 の焦點に結ばれてるなければならない所の必然性が存し，此所には 丈必然的に之等 3 者の上に立つて指導經營す各所のわのとして科學 技術が，過去の生產經營經濟が自由主義であららと，營利主義であ らろと一向に無頓着な形態に於かれ，營利追及に急々とした斯かる 經營形態と轉換し，戰爭行動と軌を一にせる皇道理念と照合すべき 經營態形に集一せるねばならない，此の技術を最高位に置き規格を中 心軸となしたろ所の 3 者渾然一體の形態が國家的單一意志の下に戰 争目的に向つて前進せねばならない，重點主義，及統制主義政策は
之れを意味するものと言へるのである。

斯樣な見地より重要座業部門の一翼を占むる電氣用磁器㥂子工業 に於ける碍子規格に就いてり亦同樣相當範圍に制定を見, 又實行さ れてはるるが, 所要數量の多大なる 部面に於てのみ實施せらろっの 現實にして過渡期に於ける方策としては肯首さる」も，已に支那事 變以來數星霜を經過し 經營態形の建直しに直面せる今日，以前と同 樣なる態形にては最早や實狀に即しないのである. 生產增强の障碍 たる無規格の儘々置かれてるる所の悠に 數千種の大小樣々な部面を も規格化せねばならない，同一系統のものにても二三十種を數るる が如き無統制系統が 幾系統もあるのである. 之れが貴重なる資源, 勞力を流消せしめ, 然も連絡工程上にも不都合を來し結肩は生產力 堙强並びに國家總動員計畫を何等の障碍もなく逐行し, 其の成果を 遺憾なく發揮せしむるに就いての险路を形づくるにあつては，決戰 完勝態勢に添ひ得ない機構をなす所以を生じ, 需要者をして益々本 時戰時の區別为なく多種多樣な 注文を發するに到らしめ, 又製造供 給者としても商略に依つて規格化への積極態度を失はしむるに到つ てるる．然しこつには無統制な現有設供を戰時下䝬產に役立たしむ るための稌儀なき事情, 各社製造型錄による注文の交錯, 設計者の 獨善性, 或は獨自性が表現されてるるための为等があるのであ る.

同一目的に使用される所の碍子が各製造者間にあつて, 各寸法を 異にして居り, 又同種なるも需要者の要求にて新設計のものの製造 を餘儀なくせるが如き，其れが歪慣的に當然とされ考へられ，需 要者はこの新設計を要求することが當然の如く思はれて居るやうで はならない. 沿面距離の變更, 機械的强度, 電氣的强度の高度化, 或は設置場所の狹湓の故を以て各部寸法の變更等, 其の他種々の理 由の下に碍子體が變更され，從つて附屬金具類に迄此の影響を及ぼ し，前記の如き變更，取付孔數，取付孔徑，取付孔相互距離，金具 の形狀等に變更を與へられてるる.之等は全體構成上より考察し， 實質的意義少き場合が多く寧ろ斯かるため製造者の浪費の甚しき事 を見逃せない幾多の矛盾は枚擧に遑がない。

尚此の外に戰爭邆行上一部資材が近時著しく需要增加を來し入手 量減少のため, 其れが代用品の考究を要するに到り規格統一上考慮 の必要を感ずるものがあり, 生產强化撗充にも支障の怪念を生じた るが，現下の生產目的，文び生産增强目的は戰争邆行上最高能率生 産を目標となし生產陣としての 企業體の健全なる發達を所期するの であるから，斯かる實情に置かるっとは言へ生產の中核をなす規格 化を放棄する事は許されないのである．銅材の如き住其の一例にし て差當り銅材に換はるものとして,アルミニュム材を利用するとす れば，銅に比し電導度，其の他の性質が稍劣るため同一容量に對し 形狀の更改が必要され，この事實が規格統一阻害の原因として一應 考へらる」のである. 然れ共之等は矢張り規格外として放置せず, 暫定的措置を講じ，已に他部門に於て定決せしめられたる如く臨特 規格, 或は暫定規格として之れに準據せしむるの方針を探り，如何 
なる新事態發生するも生锖部門の共通性は何所迄も保持に努め, 全 生產が恰子一企業體の如き體系へと組織立てられねねばならない。

以上各種關係を各品種につき例圖を以てすればよく察知なし得る 为紙數の都合上省略するとし何れにしても，世界最大の工業國を以 て任ずる米國との死鬪續行中の今日，侉斯くの如き舊態依然たる姿 にては明日の決戰を如何に迎へんか, 工業生產力瞃强は先づ以て規 格中心に立直し品種制限を行ひ，單一化を徹底し， 1 品種 1 規格に 迄押進めたいるのである. 斯くして最少資源, 最少動力, 最少勞力 を以て高度の能率を擧げ資源の均衡ある配給を計り, 現有設備を以 て大量生產樣式の確立を期さねばならないと思はれる。

斯樣に無規格, 規格嚴守の不徹底, 規格の連絡性缺如等のために 生產陣營に於ての多くの國家的損失を繰返してるるかを知る時, 總 力を擧げて最も迅速に且つ有機的連絡ある規格, 材料規格を始め, 製品規格，設計規格を制定されなければならない。然る之れを總て の生產部門の末端に迄沴透せしめ称ばならない。

根本的規格體制整備の上は機器製造者, 碍子附屬機器製造者, 碍 子磁器體製造者間には一幊せる作業工程が生れ生產作業機械部門に 於ける規格との總合が結局高能率大量生產制の確立を期し完勝への 進路が開け得るのである.

從來碍子規格制定に當つては，工業品規格調査會を始め，日本電 氣工藝委員會, 電氣協會, 電氣學會, 電氣通信協會, 電氣通信學會, 日本電機製造協會, 電氣事業者, 及其の他 各關係官廳, 碍子製造業
者を以て協議制定されたるが，其の規格間に連絡を缺き高度の目的 を達し得なかつた憾があつた。

今般重要產業團體令により，成立されたる統制會は前記連絡性及不 統一を調節するに避切なる組織體と謂ふべく其の活動こそ，特に橫 に連絡を持つ技術部局の活動こそ期待する当のであり, 縱横高深に して秩序整然たる規格を制定し其の徹底的實行を計り生産增强及搌 充に遺憾なからしめらる」を待望するものである.

\section{重要產業團體令第六條の四に}

技術, 向上, 能率, 增進, 規格ノ統一, 經營改善, 其他會員及 會員タル團體习組織スル 者, 當該產業二屬スル事業ノ發達二關 スル施設

とあり統制會の定款にも同樣の主旨が明示されてるるのである.

最近の戰況の進展, 生產擴充の五重點産業への集約化等きびしい 現實に直面してるる帝國は何所迄も勝ち通し擊ちてし止まむの意氣 を以て，この戰時生產を確保し㴰强し萬全を期さ稀ばならない。

生産增强の成否は一つに此の規格の全面的制定にある. この有機 的連熬を成す所の規格が活動體としての 產業の中心軸となり秩序あ る技術指導の下に始めて最高能率生產子生れ，企業體の健全なる發 達子生れ, 全生産陣營の完譬を築き得, 以下大東亞圈全產業の生產 昂揚への果敢なる大進軍が成し逐げらるつのである.

規格を基點とした新たなる波紋は，やがて米英擊隇への怒濤とな る確信を有し此の稿を終る。

(18. 2. 15)

\section{陶 磁を論じ染付に及ぶ}

\section{西}

人生と陶磞 戰爭をするには鐵と銅が要る事は能く分つて居る. 山に家庭に呀鏫が進められて居る。陶磁が家庭の必需品として人間 生活に缺くべからざる事は餘り知られて居ない。朝起きて御不淨に 行く其處には小便器, 大便器, 手洗器がある. 顏を洗ふには洗面器 がある、神に額づけば祭器がある. 食卓に向へぼ茶碗，且，鉢，士 瓶等澤山の食器がある. 臺所には摺鉢, 片口, 土鍋, 行本, 焜爐, 火消賞, 流し等の廚庆用具がある。客間には床の間に花瓶, 置物が あり額がある。卓の側には火鉢も安れば卓の上には煙草七ットがあ

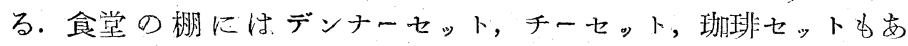
る. 生花には花瓶, 水盤がある. 抹茶には花生; 香爐, 茶碗, 茶壸, 菓子鉢, 水指, 建水等があり, 煎茶には凉爐, 湯罐, 茶注, 茶盌, 水注, 建水等がある。電氣用品としての磁器は䌊緣體として各所に 使用せられ，これなくては電報は打てず電話で話をする事も出來 ず,ラヂオを聞く事も亦電燈をつ忏る事も出來ない，执風吕に大れ ぱ床はタイル唇り，バスもある。 その廢水は土管を通じて外部へ， 特庭には雪見燈籠や榻がある。牤嘗に參詣すると駒犬や春日燈籠が ある．軍事用には自動車，バス，トラック，戰車，飛行機の點火管 は燒物である.いくらガソリンがあつても發動機の點火管が破壤し たらエンヂンが止つて 戰車は動かず飛行機は落せる。兵陵が栃水を

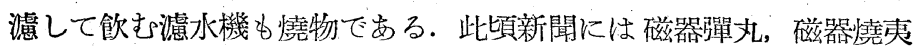
彈といふ交字がある。火藥を作るに用ゆる硝酸, 硫酸等の用器其他 化學工業製作上重要なる一部を陶磁が擔つて居る。重工業でないや らに取扱はれて居るが仰々そふでない。斯く數へると交だまだ澤山 出て來るであらうが如何に多く吾々が陶嗞の御厄介になつて居るか 驚くの外はない.
貞

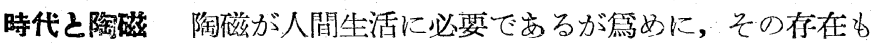
至つて古い，埃及古王國時代既に製陶の事ありといふ，外國や日本 の古い處は特預けとして近代の處を少し述べると,

鐉倉時代 此時代は加藤四郎左衞門景正が安貞 2 年 (1888) に策 “から陶技を丕得して歸朝尾張瀨戶で製陶を始めた。此間に信樂，伊 賀燒が創つた。

室町時代 當代は夌那朝鮮よりの輸大品を賞玩して居つたが茶道 が流行して志野宗信, 武野紹鷗, 千利休の指導獎勵があつた。此期 間に備前, 美濃, 唐津焅等が創つた

挑山時代 戰亂の內にも茶道が益了盛んとなり前記 3 氏の外古田 織部正の指導があり，信長，秀吉，筒井順慶の保護獎勵があり大に 發達した. 又末期に於ては文䇐の役が起りそれが終結と共に諸侯は 朝您の陶工を從へて歸り各地に製陶業を植へ付けた。郎ら萩, “平戶, 有田, 高取, 上野, 佐佐等々。

德川時代 戰亂漸く治り諸侯は先づ農を勵久，工を興さしめた。 その內でもこの陶稵は茶の流行と共に趣味のものであり, 日常缺く べからざるものでもあり大に保護獎勵され發達もした．先づ當代に 於て特筆大書すべきは元和元年 (2275) 森參本に依て有田泉山の土 で白磁が作り出された事で嵓る。坴年五郎太夫祥瑞が歸朝して染付 磁器を燒いた. 正保 3 年(2305)周辰官が酒井田柿右衞門に赤繪を傳 授し叠年柿右衞門は赤繪染付に成功した. 後藤于次郎は寬文 6 年 (2326) 肥前の磁法を以て九谷に製磁を創め, 延罆 2 年 (2334) 久隅 守景は九谷堯に繪付をした. 文化 4 年 (2467) 加藤民吉は肥前の磁 法を瀨戶に傳へた. 斯くて有田から九谷, 瀨戸に磁法が傳はり千宗 且, 小堀遠州は茶道により信樂, 志戸, 膳所, 上野, 高取, 朝日, 